\title{
The relationship between the acetylator and the sparteine hydroxylation polymorphisms
}

\author{
D HARMER, D A P EVANS*, L C EZE†, M JOLLY, ANDE J WHIBLEY \\ From the Nuffield Unit of Medical Genetics, Department of Medicine, University of Liverpool, PO Box 146, \\ Liverpool L69 3BX.
}

SUMmaRY Thirty-eight healthy white British Caucasian subjects were hydroxylator phenotyped with sparteine and acetylator phenotyped with sulphadimidine. The results showed that there was no significant difference in the mean sparteine metabolic ratio between eight rapid acetylator extensive hydroxylators and 27 slow acetylator extensive hydroxylators.

There are two well known genetic polymorphisms of drug metabolism in man. The first governs the acetylation of isoniazid sulphadimidine hydralazine, ${ }^{1}$ dapsone,${ }^{2}$ procaine amide,${ }^{34}$ sulphapyridine, ${ }^{5}$ a reduced metabolite of nitrazepam, ${ }^{6}$ and a metabolite of caffeine. ${ }^{7}$ The $\mathrm{N}$-acetyl transferase enzyme which exhibits polymorphic activity is cytosolic in liver and jejunal mucosa. ${ }^{8}$ The second governs the hydroxylation of debrisoquine, ${ }^{9}$ sparteine,$^{10}$ phenacetin ${ }^{11}$ metroprolol, ${ }^{12}$ propranolol, ${ }^{13}$ bufuralol, ${ }^{14}$ guanoxon, ${ }^{15}$ and perhexilene. ${ }^{16}$ The polymorphic enzyme is a liver P450. ${ }^{17}$

A population of healthy subjects has been exmined for evidence of interaction between the two polymorphisms.

\section{Materials and methods}

Ethical clearance for these experiments was given by the Ethical Committee of the Mersey Regional Hospitals Board and all subjects also gave their informed consent. Thirty-eight healthy white British Caucasian subjects were investigated by means of two phenotyping procedures.

The acetylator phenotyping procedure was carried out with sulphadimidine ${ }^{18}$ and the hydroxylator phenotyping was carried out with sparteine. ${ }^{19}$ The two phenotyping tests were carried out at least ten days apart. The analytical procedures for the acetylator phenotyping ${ }^{20}$ and hydroxylator phenotyping ${ }^{19}$ were carried out by means of standard published methods.

\section{Results}

The acetylator phenotyping information is shown in

*Present address: C123 Riyadh Armed Forces Hospital, PO Box 7897, Riyadh 11159. Kingdom of Saudi Arabia. †Present address: Department of Biochemistry, University of Nigeria, Nsukka, Nigeria.

Received for publication 10 September 1984.

Revised version accepted for publication 1 March 1985. fig 1 . Ten rapid and 27 slow acetylators were found. The results from the subject with an unclear acetylator phenotyping result (a poor hydroxylator) were not considered further in the analysis.

The hydroxylator phenotyping information within both acetylator phenotypes is shown in fig 2 . The

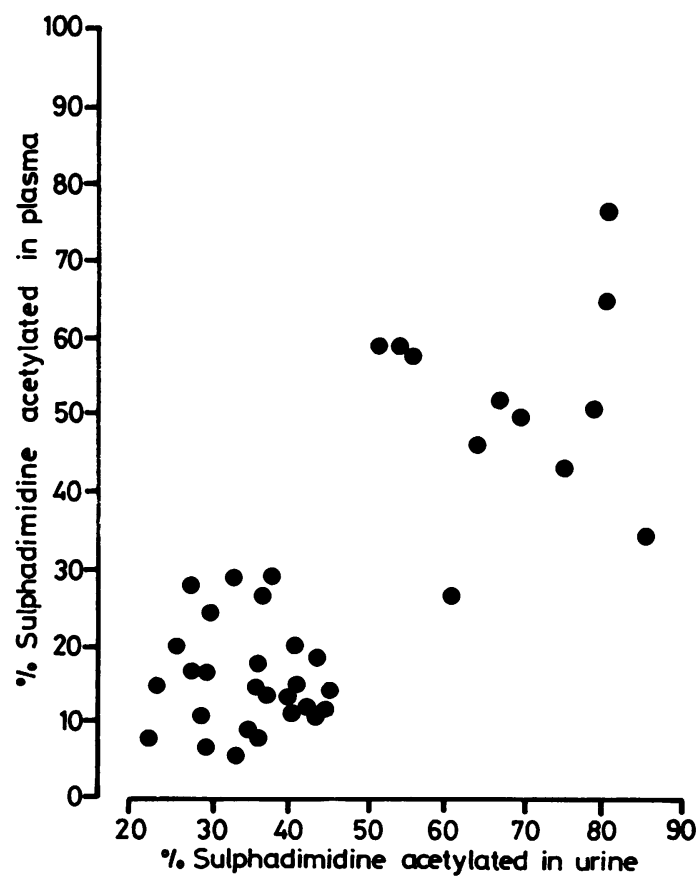

FIG 1 The acetylator phenotyping data on the 38 healthy volunteer subjects. The single subject with the anomalous result ( $a$ high acetylation percentage in urine and a low acetylation percentage in plasma) was not included in further analyses. 


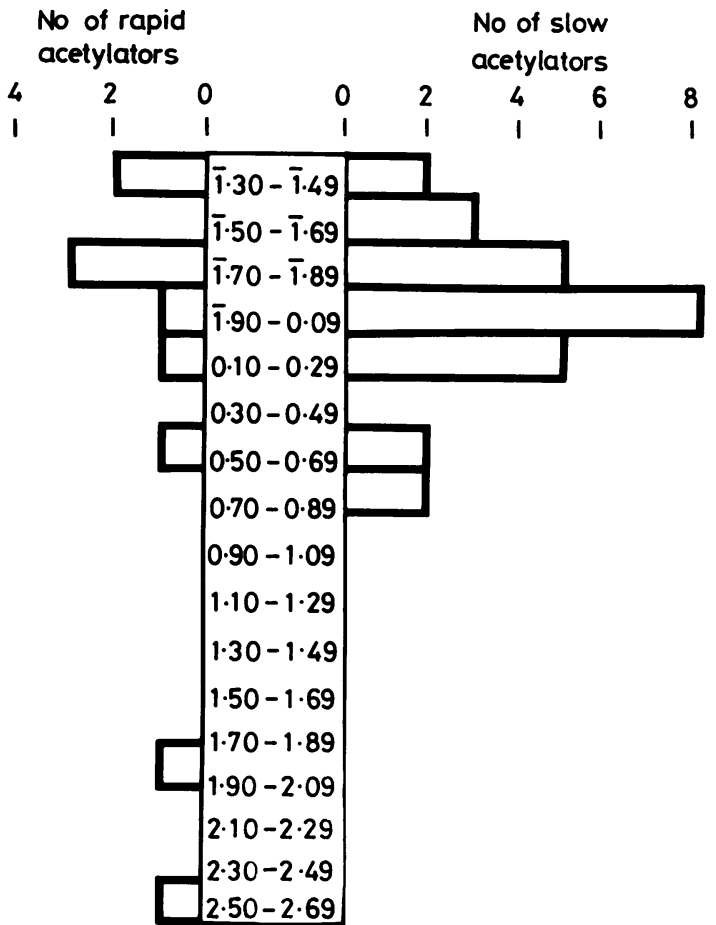

$\log _{10}$ Sparteine MR

FIG 2 The frequency distributions of $\log _{\iota 0}$ sparteine metabolic ratio in urine in subjects of both acetylator phenotypes.

mean $\log _{10}$ sparteine metabolic ratio for eight rapid acetylators and extensive hydroxylators was $1.9002 \pm 0.1423$ SEM, whereas the mean $\log _{10}$ sparteine metabolic rate for 27 slow acetylators and extensive hydroxylators was $0 \cdot 0155 \pm 0 \cdot 0700$ SEM. Comparison of these two means reveals $\mathrm{t}=0.77$, and so with 33 degrees of freedom $\mathrm{p}>0 \cdot 05$.

Two rapid acetylator poor hydroxylators were identified as shown in fig 2.

\section{Discussion}

In this sample there were too few poor hydroxylators to be able to say whether or not the two polymorphisms are genetically independent.

The rapid acetylator extensive hydroxylators had a mean sparteine metabolic ratio which was not significantly different from that of the slow acetylator extensive hydroxylators. This finding is as expected since the biochemical transformations governed by the two polymorphisms are quite different. Sparteine hydroxylation is performed in the endoplasmic reticulum in vivo (microsomes in vitro), while $\mathrm{N}$ acetylation is a cytosolic activity.

\section{References}

1 Evans DAP, White TA. Human acetylation polymorphism. J Lab Clin Med 1964;63:394-403.

2 Gelber R, Peters JH, Gordon GR, Glazko AJ, Levy L. The polymorphic acetylation of dapsone in man. Clin Pharmacol Ther 1971;12:225-38,

3 Gibson TP, Matusik J, Matusik E, Nelson HA, Wilkinson J, Briggs WA. Acetylation of procaineamide in man and its relationship to isonicotinic acid hydrazide acetylation phenotype. Clin Pharmacol Ther 1975;17:395-9.

4 Karlsson E, Molin I. Polymorphic acetylation of procaine amide in healthy subjects. Acta Med Scand 1975;197:299-302.

5 Schröder H, Evans DAP. The polymorphic acetylation of sulphapyridine in man. $J$ Med Genet 1972;9:168-71.

6 Karim AKMB, Evans DAP. Polymorphic acetylation of nitrazepam. J Med Genet 1976;13:17-9.

7 Grant DM, Tang BK, Kalow W. Polymorphic N-acetylation of a caffeine metabolite. Clin Pharmacol Ther 1983:33:355-9.

\& Jenne JW. Isoniazid acetylation by human liver and intestinal mucosa. Fed Proc 1963:22:540A.

9 Mahgoub A, Dring LG, Idle JR, Lancaster R, Smith RL. Polymorphic hydroxylation of debrisoquine in man. Lancet 1977;ii:584-6.

10 Eichelbaum M, Spannbrucker N, Dengler HJ. A probable genetic defect in the metabolism of sparteine. In: Gorrod JW ed. Biological oxidation of nitrogen. Amsterdam: ElsevierNorth Holland, 1978:113-8.

1 Devonshire HW, Kong I, Cooper M, Sloan TP, Idle JR, Smith RL. The contribution of genetically determined oxidation status to inter-individual variation in phenacetin disposition. $\mathrm{Br}$ J Clin Pharmacol 1983:16:157-66.

12 Lennard MS, Silas JH, Freestone S, Trevethick J. Defective metabolism of metoprolol in poor hydroxylators of debrisoquine. Br J Clin Pharmacol 1982;14:301-3.

13 Shah RR, Oates NS, Idle JR, Smith RL. Beta blockers and drug oxidation status. Lancet 1982;i:508-9.

14 Dayer P, Balant L, Kupfer A, Courvoisier F, Fabre J. Contribution of the genetic status of oxidative metabolism to variability in the plasma concentrations of beta-adrenergic blocking agents. Eur J Clin Pharmacol 1983;24:787-99.

15 Sloan TP, Mahgoub A, Lancaster R, Idle JR, Smith RL. Polymorphisms of carbon oxidation of drugs and clinical implications. Br Med J 1978;ii:655-7.

16 Cooper RG, Evans DAP, Whibley EJ. Polymorphic hydroxylation of perhexilene maleate in man. J Med Genet 1984;21 27-33.

17 Davies DS, Kahn GC, Murray S, Brodie MJ, Boobis AR Evidence for an enzymatic defect in the 4-hydroxylation of debrisoquine by human liver. Br J Clin Pharmacol 1981;11: 89-91.

18 Evans DAP. An improved and simplified method of detecting the acetylator phenotype. J Med Genet 1969;6:405-7.

19 Eichelbaum M, Spannbrucker N, Steincke B, Dengler HJ. Defective $\mathrm{N}$-oxidation of sparteine in man: a new pharmacogenetic defect. Eur J Clin Pharmacol 1979;16:183-7.

20 Eze LC, Evans DAP. The use of the Autoanalyser to determine the acetylator phenotype. J Med Genet 1972;9:57-9.

Correspondence and requests for reprints to Dr DA Price Evans, Department of Medicine, C123 Riyadh Armed Forces Hospital, PO Box 7897, Riyadh 11159, Kingdom of Saudi Arabia. 